\title{
FUNCTIONAL PROPERTIES OF PROTEIN CONCENTRATE FROM BLACK COWPEA AND ITS APPLICATION
}

\author{
Anuchita Moongngarm, Sirinapa Sasanam, \\ Watcharee Pinsiri, Puttarat Inthasoi, Sakawduen Janto and Jutharat Pengchai \\ Department of Food Technology and Nutrition, Faculty of Technology, \\ Mahasarakham University, Mahasarakham 44150, Thailand
}

Received 2014-08-22; Revised 2014-10-27; Accepted 2014-11-29

Funding: Mahasarakham University, Thailand, grant number 2556A10902065

Competing Interests: The authors have declared that no competing interests exist

\begin{abstract}
Black cowpea (Vigna unguiculata L. Walp.) is high in protein, which makes it suitable for use as a protein supplement in food products. However, direct application of cowpea flour in food products is limited as it may affect some quality aspects of foods. Protein concentrate and isolate are a form of the protein that is gaining interest in industry. Therefore, this study was carried out to compare functional properties of Cowpea Protein Concentrate (CPC) prepared using three different methods: (1) Isoelectric point (pI) Precipitation (CPC-pI), (2) ammonium sulfate precipitation and (3) pI-ammonium sulfate precipitation. The results showed that the protein concentrate prepared using $\mathrm{pH}$ adjustment provided the maximum yield of $17.92 \%$, followed by the precipitation of proteins with ammonium sulfate with hydrochloric acid $(15.05 \%)$, whereas the precipitation with ammonium sulfate yielded lowest amount (9.82\%). The protein concentrate prepared by CPC-pI had the highest protein content of $85.89 \%$, followed by CPC precipitated with ammonium sulfate with the hydrochloric acid $(79.35 \%)$ and protein concentrate precipitated with ammonium sulfate $(68.28 \%)$, respectively. CPC-pI had functional properties, including solubility, viscosity, water and oil holding capacity, foam ability, emulsion stability and gelation ability superior to CPC prepared by other methods. For the study on the application of CPC$\mathrm{pI}$ to prepare sugar cookies, it was found that CPC could be used to replace wheat flour as much as $60 \%$ with comparable panelist acceptance to wheat flour cookie.
\end{abstract}

Keywords: Cowpea, Protein Concentrate, Functional Property, Solubility, Emulsifying Property

\section{INTRODUCTION}

Black cowpea is a legume that grows well in tropical countries and yields high productivity. It is also a good source of nutrients composed of $67-50 \%$ carbohydrates, of which about $20-10 \%$ of the starch is resistant. It is a good source of protein and provides a significant amount of dietary protein. Plant protein, which is commonly used in food products such as legumes, is interesting due to the fact that legumes are generally high in protein. It is one of the most popular legumes grown in Thailand, but mainly it is used for sweet food products. In order to take advantage of the cowpea, processing it into some base foods may yield some interesting results. As cowpea is high in protein, it is suitable for using as a protein supplement in food products. However, application directly of cowpea flour may not be suitable because its contents could affect some quality aspects of food products. Therefore, it is important to prepare in other forms of base food products. Protein concentrate and Corresponding Author: Anuchita Moongngarm, Department of Food Technology and Nutrition, Faculty of Technology, Mahasarakham University, Mahasarakham 44150, Thailand 
isolates are base food products gaining interest in the food industry. In order to successfully apply a CPC into any food item, it is necessary to find out the suitability of its functional properties for food applications and consumer acceptability. The important functional properties of CPC are solubility, foaming ability, gelation and emulsifying properties, all of which can affect the quality of food. Therefore, it is important to investigate the functional properties of CPC so they can be useful and successful in food application. The information gained can be used as a basis for its applications. The present study was aimed to study the chemical composition and functional properties of CPC prepared from different techniques and then study its application in a food product.

\section{MATERIALS AND METHODS}

\subsection{Samples and Preparation of Cowpea Flours}

Black cowpea seeds were used in this study. They were purchased from a local market in Mahasarakham province, Thailand. The whole seed and decorticated seed flour was prepared according to Sasanam et al. (2011) and their proximate compositions were determined using AOAC methods (AOAC, 2000).

\subsection{Preparation of Protein Concentrate}

The cowpea flour samples were prepared in three replicates. The flour was tray dried at $45 \pm 2{ }^{\circ} \mathrm{C}$ to reach $10 \%$ of moisture content and storage at $4^{\circ} \mathrm{C}$ until used. The CPC was prepared by three different techniques including (1) isoelectric point precipitation (CPC-pI), (2) Ammonium sulfate precipitation (CPC-AM) and (3) Ammonium sulfate combined with isoelectric point precipitation (CPC-AM-pI).

\subsection{Preparation of CPC-pI}

The CPC-pI was obtained using the method of Fernandez-Quintela et al. (1997) with some modifications. The flours were dissolved in distilled water $(1: 5(\mathrm{w} / \mathrm{v})$ and the $\mathrm{pH}$ of the suspension was adjusted to $\mathrm{pH} 8.0$ with $1 \mathrm{~N} \mathrm{NaOH}$. The mixture was stirred at room temperature for $60 \mathrm{~min}$ prior to centrifuging at $4000 \times \mathrm{g}$ and $20^{\circ} \mathrm{C}$ for $20 \mathrm{~min}$. The insoluble portions were disposed of. The supernatant was adjusted to $\mathrm{pH} 4.5$ with $1.0 \mathrm{~N} \mathrm{HCl}$ and stirred at room temperature for $20 \mathrm{~min}$ before setting protein to precipitate at $4^{\circ} \mathrm{C}$ for $3 \mathrm{~h}$. The mixture was centrifuged at $4000 \times \mathrm{g}$ and $4^{\circ} \mathrm{C}$ for $20 \mathrm{~min}$. The residue was washed using distilled water and then neutralized to $\mathrm{pH} 7.0$ using $1.0 \mathrm{~N} \mathrm{NaOH}$ prior to drying using freeze-drying. The CPC-pI obtained was stored in a refrigerator until used.

\subsection{Preparation of CPC-AM}

CPC-AM was obtained using the method described by Lampart-Szczapa (1996) with minor modifications. The cowpea flour was suspended in distilled water and added with concentrate ammonium salt) $40 \%$, $\mathrm{NH}_{4}\left({ }_{2} \mathrm{So}_{4}\right)$ and then stirred for $2 \mathrm{~h}$ at room temperature. The suspension was centrifuged at $4000 \times \mathrm{g}$ for $30 \mathrm{~min}$ and the precipitating portion was obtained and the liquid portion was extracted again as described above. The precipitate portion was combined and diluted tenfolds by distilled water and left to stand at $4^{\circ} \mathrm{C}$ for $18 \mathrm{~h}$. The supernatant was removed and the precipitate was centrifuged at $4000 \times \mathrm{g}\left(4^{\circ} \mathrm{C}\right)$ for $20 \mathrm{~min}$. The precipitate protein was dried using freeze-drying to obtain CPC-AM.

\subsection{Preparation of CPC-AM-pI}

The cowpea flour was suspended in distilled water and added with concentrate ammonium salt) $40 \%$, $\mathrm{NH}_{4}\left({ }_{2} \mathrm{So}_{4}\right)$, then stirring for $2 \mathrm{~h}$ at room temperature. The $\mathrm{pH}$ of the suspension was then adjusted to $\mathrm{pH} 8.0$ with 1 $\mathrm{N} \mathrm{NaOH}$ and the remaining steps were done by following the method used in the preparation of CPC-pI.

\subsection{Chemical Analysis}

The chemical compositions of protein concentrates were determined using AOAC methods (AOAC, 2000).

\subsection{Functional Properties}

CPC obtained was measured for functional properties, including water solubility, water and oil absorption capacity, emulsifying capacity, emulsifying stability and gel capacity.

\subsubsection{Water Holding Capacity (WHC) and Oil Binding Capacity (OBC)}

WHC of protein isolates was determined using the method of (Quinn and Paton, 1979). The CPC (1 g) was mixed with $10 \mathrm{ml}$ of distilled water or soybean oil, mixed well with a vortex at maximum speed for $1 \mathrm{~min}$ and then leftto stand at room temperature $(28 \pm 2)$ for 30 min prior to centrifuging at $25^{\circ} \mathrm{C}$ at $8,000 \times \mathrm{g}$ for 20 min. The supernatant was decanted and left to drain for 15 min, before weighing the remaining residue. The WHC was expressed as the number of gram of water held by $1.0 \mathrm{~g}$ of CPC and the OBC was expressed as the number of grams of oil held by $1.0 \mathrm{~g}$ of CPC, using the following formulas:

$$
W H C(g / g)=\frac{\text { weight of sample after centrifuged }(g)}{\text { Initial weight of sample }(g)}
$$




$$
O B C(g / g)=\frac{\text { weight of sample after centrifuged }(g)}{\text { Initial weight of sample }(g)}
$$

\subsubsection{Emulsifying Activity (EA) and Stability (ES)}

The evaluation o Emulsion Activity and Stability of protein concentrate was modified from (Mutilangi and Panyam, 1996). CPC samples were dissolved in distilled water to prepare $1 \%$ concentration (w/vol). CPC solution $(30 \mathrm{~mL})$ was added with $20 \mathrm{~mL}$ of soybean oil and homogenized at a speed of $10,000 \mathrm{rpm}$ for $1 \mathrm{~min}$ at room temperature (about $25^{\circ} \mathrm{C}$ ). The emulsion was poured into $100 \mathrm{ml}$ graduated cylinder to measure the total volume of the emulsion and the oil layer after setting for $60 \mathrm{~min}$ for EA and 180 min for ES:

$$
\frac{E A \%=\text { Total volume of emulsion remaining after } 60 \mathrm{~min} \times 100}{\text { Total volume of emulsion }}
$$

ES $\%=$ Total volume of emulsion remaining after $180 \mathrm{~min} \times 100$ Total volume of emulsion(initial)

\subsubsection{Foaming Capacity (FC) and Foam Stability (FS)}

FC and FS were measured according to the method described by Liceaga-Gesualdo and Li-Chan (1999) with some modifications. The CPC (500 mg) was dissolved in $50 \mathrm{~mL}$ of de-ionized water and the $\mathrm{pH}$ was adjusted to 6.5 with diluted hydrochloric concentration. The volume of the solution was measured using $100 \mathrm{~mL}$ graduated cylinder. The solutions were stirred using homogenizer at a speed of $10,000 \mathrm{rpm}$ for $3 \mathrm{~min}$. The blend was immediately transferred into a $100 \mathrm{~mL}$ graduated cylinder to measure the volume of foam.

FC was expressed as the volume (\%) increased due to stirring. For the determination of FS, foam volume changes in the graduated cylinder were recorded at 30 min of storage. FC and FS were calculated as followings:

$\frac{F C \%=(\text { Volume after whipping }- \text { volume before whipping }) \times 100}{\text { Volume before whipping }}$

FS $\%=($ Volume after standing - volume before whipping $) \times 100$ Volume before whipping

\subsubsection{Solubility Capacity}

This was determined according to the modified methods of (Rodriguez-Ambriz et al., 2008). The CPC
$400 \mathrm{mg}$ was dispersed in $20 \mathrm{~mL}$ of de-ionized water and $\mathrm{pH}$ of the mixture was adjusted to 3-11 and 12 with $1 \mathrm{~N} \mathrm{HCl}$ and $1 \mathrm{~N} \mathrm{NaOH}$. The samples were shaken using a shaker at $150 \mathrm{rpm}$ for $45 \mathrm{~min}$ at room temperature before being centrifuged at $5000 \times \mathrm{g}$ for $15 \mathrm{~min}$ (Ragab et al., 2004). The protein content in the supernatant was analyzed for protein by Biuret method. Protein solubility was then calculated using formula as following.

$$
\text { Solubility } \%=\frac{\text { Protein content in supernatant } \times 100}{\text { Total protein content in sample }}
$$

\subsubsection{Gelation Capacity}

Least gelation concentration was evaluated using the method of Coffman and Garcia (1977).

\subsection{Preparation of Rice Sugar Cookies}

The preparation of sugar cookies was done following the method of AACC (2011). The basic ingredients of sugar cookies were Wheat Flour (WF), sugar, pasteurized milk, egg yolk, butter and CPC-pI. The five cookie formulas were prepared by replacing CPC-pI to WF (CPC: WF) in five different replacement levels, including 0:100 (served as control), 50:50, 60:40, 70:30, $80: 20$ and 90:10. The sugar cookies were used for chemical composition analysis, calorie evaluation (calculated from protein, fat and carbohydrate content) and sensory evaluation.

\subsection{Sensory Evaluation}

The cookie samples were freshly prepared for sensory evaluation. The samples were placed in small containers and served immediately. The cookie was evaluated for appearance, flavor, taste, texture and overall liking by 30 untrained panelists using 9-point hedonic scales, where $9=$ extremely like and $1=$ extremely dislike. Each panelist evaluated six samples (identified by unique three-digit codes) in a balanced sequential order. The optimal ratio of CPC-pI to wheat flour in the cookie was evaluated using sensory qualities in comparison to the control samples.

\subsection{Statistic Analysis}

All results of triplicate samples were statistically analyzed using SPSS (Demo version) for windows. The results of individual samples are reported as the mean \pm standard deviation. The Duncan's Multiple Range Test (DMRT) was applied for mean comparison when analysis of variance showed significant differences at 95\% confidence level. 


\section{RESULTS}

\subsection{Chemical Compositions of CPC}

The proximate compositions of cowpea flours and CPC prepared from different techniques are shown in Table 1. The moisture content was higher in cowpea flour due to the fact that flour was directly prepared from dried seed whereas the CPC was obtained using freeze drying. The protein content was highest in CPC-pI $(85.89 \%)$, followed by CPC-AM-pI $(79.35 \%)$ and CPCAM $(68.27 \%)$. There was only trace amount of fat content in CPC and 1.40 to $1.48 \%$ in cowpea flour. Similar results to fat content were found in fiber content. The ash contents ranged between 3.14 and $4.25 \%$, which the highest amount was observed in the whole seed flour.

The free amino acid content is presented in Table $\mathbf{1 .}$ The CPC-pI had the highest amount of free amino acids $(37.70 \%)$, followed by CPC-AM-pI and CPC-AM.

\subsection{Functional Properties of CPC}

\subsubsection{Water Holding Capacity (WHC) and Oil Binding Capacity (OBD)}

The WHC and OBD of CPC obtained from three different techniques was significantly different (Table 2). The CPC-pI showed the greatest WHC and OBC (1.40 $\mathrm{g} / \mathrm{g}$ and $5.26 \mathrm{~g} / \mathrm{g}$, respectively), followed by CPC-AMpI with the value of $1.09 \mathrm{~g} / \mathrm{g}$ for $\mathrm{WHC}$ and $3.08 \mathrm{~g} / \mathrm{g}$ for $\mathrm{OBC}$, whereas the lowest $\mathrm{WHC}$ and $\mathrm{OBC}$ was observed in CPC-AM.

\subsubsection{Foaming Ability}

The foaming ability of CPC, obtained from three different methods, was significantly different as indicated in Table 2 . The ability of protein concentrates to bubble up was found. The extraction of protein with $\mathrm{pH}$ adjustment (CPC-pI) had the greatest foaming ability, followed by that using ( $\mathrm{NH} 4)_{2} \mathrm{SO}_{4}$ with hydrochloric acid CPC-AM-pI) (87.66 and $80.87 \%$, respectively), whereas CPC obtained by salt precipitation $\left((\mathrm{NH} 4)_{2} \mathrm{SO}_{4}\right)$ had lowest ability. For foaming stability, the methods of protein extraction and precipitation were also influenced the foaming stability. CPC-pI showed the most stability $(74.02 \%)$ whilst the CPC-AM-pI and CPC-AM were 67.44 and 59.13, respectively.

\subsubsection{Emulsifying Activity and Stability}

The evaluation of emulsifying activity and stability of CPC samples is shown in Table 2. The results reveal that the preparation methods used significantly affected the emulsifying and stability of CPC. The highest emulsifying activity was observed in CPC-pI (80.25\%), followed by CPC-Am-pI and CPC-AM $(73.41 \%$ and $67.37 \%$, respectively). Similar results were obtained with the emulsifying stability, i.e., the greatest stability was found in CPC-pI.

\subsubsection{Gelation of the Protein Concentration}

Gelation is an aggregation of denatured molecules. The results of gel formation of $\mathrm{CPC}$ obtained from different methods are presented in Fig. 1. The results show that all CPC samples were not able to form gel at concentration lower than $12 \%$. On the other hand, gelation was observed for CPC-pI at 14\% (w/v).

\subsubsection{The Solubility of CPC}

The solubility results of the CPC show that the precipitation methods affect protein solubility. The protein $\mathrm{pH}$-solubility profiles of CPC-pI, CPC-AM-pI and CPC-AM are shown in Fig. 1. The protein solubility of all CPC samples show the same U-shaped curves similar to the protein solubility profiles reported for peanut proteins ( $\mathrm{Yu}$ et al., 2007), for cashew nuts (Ogunwolu et al., 2009) and for walnut (Mao and Hua, 2012). Protein solubility of CPC from different precipitation methods was similar. They are minimal in the range of 4.0-5.0 and then increase as the sample $\mathrm{pH}$ increases. Similar results were also observed in walnut protein as reported by (Sathe et al., 1982). All CPC samples presented minimum proteins solubility at $\mathrm{pH} 4.5$ with values of $1.53 \%, 1.59$ and $1.68 \%$ for CPC-AM-pI, CPC-pI and CPC-AM, respectively and maximum protein solubility at $\mathrm{pH} 12$ with values of $51.90,53.31$ and $48.66 \%$ for CPC-AMpI, CPC-pI and CPC-AM, respectively.

\subsection{Application of CPC in Sugar Cookie}

\subsubsection{Chemical compositions of Sugar Cookies}

The chemical compositions of cookies prepared from wheat flour and CPC-pI substituted for wheat flour are presented in (Table 3).

The moisture contents of the cookies varied from 1.21 to $4.36 \%$. The moisture content of cookies prepared from wheat flour (served as control) was significantly lower than those prepared from CPC and wheat flour blends with different ratios. The cookies from wheat flour indicated the lowest protein content $(19.86 \%)$ whereas cookies prepared from wheat flour replaced by CPC had protein content ranging between 35.29 and $43.03 \%$. 


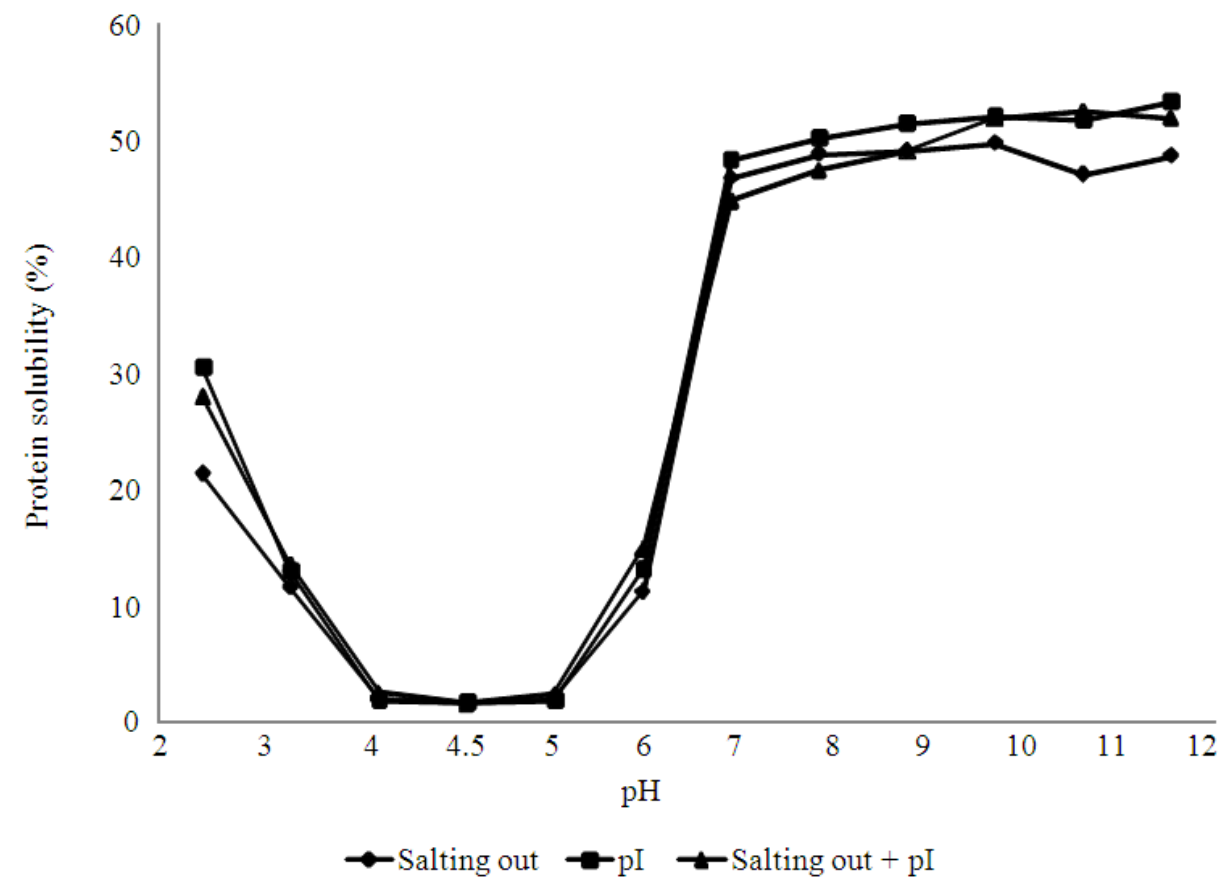

Fig. 1. Protein solubility of cowpea protein concentrates prepared using different techniques

Table 1. Chemical compositions of black cowpea flour and Cowpea Protein Concentrate (CPC) (\%)

\begin{tabular}{llllll}
\hline Composition & Whole seed flour & Decorticated seed flour & CPC-pI & CPC-AM & CPC-AM-pI \\
\hline Moisture & $7.80 \pm 0.17^{\mathrm{a}}$ & $8.24 \pm 0.35^{\mathrm{a}}$ & $5.43 \pm 0.85^{\mathrm{b}}$ & $4.73 \pm 0.27^{\mathrm{c}}$ & $5.01 \pm 0.69^{\mathrm{bc}}$ \\
Protein & $20.98 \pm 3.28^{\mathrm{d}}$ & $21.53 \pm 2.66^{\mathrm{d}}$ & $85.89 \pm 2.24^{\mathrm{a}}$ & $68.27 \pm 2.02^{\mathrm{c}}$ & $79.35 \pm 1.93^{\mathrm{b}}$ \\
Fat & $1.48 \pm 0.33^{\mathrm{b}}$ & $1.40 \pm 0.44^{\mathrm{a}}$ & trace & trace & trace \\
Ash & $4.25 \pm 0.13^{\mathrm{a}}$ & $3.32 \pm 0.35$ & $3.87 \pm 0.12$ & $3.91 \pm 0.44$ & $3.14 \pm 0.31$ \\
Fiber & $3.35 \pm 0.09^{\mathrm{a}}$ & $2.49 \pm 0.07^{\mathrm{a}}$ & trace & trace & trace \\
Carbohydrate & $62.96 \pm 1.77$ & $66.46 \pm 1.75$ & $8.64 \pm 0.08$ & $11.72 \pm 0.10$ & $10.65 \pm 0.06$ \\
Total free amino acid & & & & & \\
(mg/100g) & $7.23 \pm 0.041^{\mathrm{c}}$ & $3.60 \pm 0.16^{\mathrm{d}}$ & $37.70 \pm 1.05^{\mathrm{a}}$ & $18.46 \pm 0.77^{\mathrm{c}}$ & $31.18 \pm 1.39^{\mathrm{b}}$ \\
Product yield $(\%)$ & $88.46 \pm 1.75^{\mathrm{a}}$ & $81.19 \pm 2.02^{\mathrm{b}}$ & $17.92 \pm 1.37^{\mathrm{c}}$ & $9.82 \pm 0.52^{\mathrm{e}}$ & $15.05 \pm 1.28^{\mathrm{d}}$ \\
\hline
\end{tabular}

Means within rows followed by the same letter are not significant different at $\mathrm{p}<0.0$

Table 2. Functional properties of cowpea protein concentrates prepared using different techniques

\begin{tabular}{llll}
\hline Functional Properties & CPC-pI & CPC-AM & CPC-AM-pI \\
\hline Water holding capacity & $1.40 \pm 0.06^{\mathrm{a}}$ & $0.78 \pm 0.06^{\mathrm{c}}$ & $1.09 \pm 0.04^{\mathrm{b}}$ \\
Oil holding capacity & $5.26 \pm 0.24^{\mathrm{a}}$ & $2.60 \pm 0.29^{\mathrm{c}}$ & $3.08 \pm 0.16^{\mathrm{b}}$ \\
Foam ability & $87.66 \pm 3.87^{\mathrm{a}}$ & $69.88 \pm 5.71^{\mathrm{c}}$ & $80.88 \pm 5.20^{\mathrm{b}}$ \\
Foam stability & $74.02 \pm 5.19^{\mathrm{a}}$ & $59.13 \pm 3.62^{\mathrm{c}}$ & $67.44 \pm 5.12^{\mathrm{b}}$ \\
Emulsifying ability & $80.25 \pm 3.66^{\mathrm{a}}$ & $67.37 \pm 4.24^{\mathrm{c}}$ & $73.41 \pm 3.50^{\mathrm{b}}$ \\
Emulsifying stability & $66.88 \pm 2.84^{\mathrm{a}}$ & $57.41 \pm 2.26^{\mathrm{b}}$ & $64.97 \pm 2.10^{\mathrm{a}}$ \\
Gel ability (\% concentration) & & - & - \\
2 to 12 & - & - & - \\
14 & + & + & + \\
16 & + & + & + \\
18 & + & + & + \\
20 & + & + & \\
\hline
\end{tabular}

Means within rows followed by the same letter are not significant different at $\mathrm{p}<0.05$ 
Table 3. Chemical compositions of cookie prepared from wheat flour and wheat flour blended with CPC with different degree of substitutions (CPC: WF)

\begin{tabular}{lllllll}
\hline CPC: WF & Moisture & Protein & Fat & Ash & Carbohydrate & Energy $($ Kcal $)$ \\
\hline$(90: 10)$ & $4.36 \pm 0.04^{\mathrm{a}}$ & $43.03 \pm 2.57^{\mathrm{a}}$ & $18.25 \pm 0.15^{\mathrm{d}}$ & $2.96 \pm 0.06^{\mathrm{a}}$ & $29.34 \pm 0.08^{\mathrm{e}}$ & $453.73 \pm 20.11^{\mathrm{b}}$ \\
$(80: 20)$ & $4.32 \pm 0.06^{\mathrm{a}}$ & $39.41 \pm 0.16^{\mathrm{a}}$ & $18.40 \pm 0.01^{\mathrm{d}}$ & $2.68 \pm 0.01^{\mathrm{b}}$ & $31.28 \pm 0.40^{\mathrm{d}}$ & $448.36 \pm 22.10^{\mathrm{b}}$ \\
$(70: 30)$ & $4.23 \pm 0.02^{\mathrm{ab}}$ & $38.32 \pm 0.08^{\mathrm{a}}$ & $19.26 \pm 0.39^{\mathrm{c}}$ & $2.64 \pm 0.04^{\mathrm{b}}$ & $32.55 \pm 0.13^{\mathrm{c}}$ & $456.82 \pm 16.07^{\mathrm{b}}$ \\
$(60: 40)$ & $4.17 \pm 0.05^{\mathrm{b}}$ & $35.96 \pm 0.56^{\mathrm{b}}$ & $19.96 \pm 0.04^{\mathrm{b}}$ & $2.44 \pm 0.03^{\mathrm{c}}$ & $34.24 \pm 0.06^{\mathrm{b}}$ & $460.44 \pm 12.23^{\mathrm{b}}$ \\
$(50: 50)$ & $4.04 \pm 0.08^{\mathrm{b}}$ & $35.29 \pm 106^{\mathrm{b}}$ & $20.27 \pm 0.09^{\mathrm{b}}$ & $2.34 \pm 0.01^{\mathrm{d}}$ & $34.54 \pm 0.15^{\mathrm{b}}$ & $461.75 \pm 19.18^{\mathrm{b}}$ \\
$(0: 100)$ & $1.21 \pm 0.21^{\mathrm{c}}$ & $19.86 \pm 0.30^{\mathrm{c}}$ & $23.75 \pm 0.05^{\mathrm{a}}$ & $1.36 \pm 0.08^{\mathrm{e}}$ & $61.56 \pm 0.60^{\mathrm{a}}$ & $539.43 \pm 10.02^{\mathrm{a}}$
\end{tabular}

Means within columns followed by the same letter are not significant different at $\mathrm{p}<0.05$

Table 4. Cookies used protein concentrations of black cowpea flour substitute

\begin{tabular}{llllll}
\hline CPC: Wheat flour & Color & Odor & Flavor & Texture & Overall liking \\
\hline$(90: 100)$ & $3.90 \pm 0.37^{\mathrm{d}}$ & $3.70 \pm 0.55^{\mathrm{d}}$ & $3.36 \pm 0.60^{\mathrm{e}}$ & $3.26 \pm 0.48^{\mathrm{e}}$ & $3.76 \pm 0.63^{\mathrm{c}}$ \\
$(80: 20)$ & $4.33 \pm 0.49^{\mathrm{d}}$ & $3.86 \pm .52^{\mathrm{d}}$ & $3.83 \pm 0.53^{\mathrm{de}}$ & $3.60 \pm 0.56^{\mathrm{de}}$ & $4.00 \pm 0.61^{\mathrm{c}}$ \\
$(70: 30)$ & $5.63 \pm 0.63^{\mathrm{c}}$ & $4.66 \pm 0.65^{\mathrm{c}}$ & $4.43 \pm 0.56^{\mathrm{cd}}$ & $4.40 \pm 0.96^{\mathrm{cd}}$ & $4.70 \pm 0.55^{\mathrm{bc}}$ \\
$(60: 40)$ & $6.60 \pm 0.37^{\mathrm{b}}$ & $5.80 \pm 0.49^{\mathrm{bc}}$ & $6.50 \pm 0.84^{\mathrm{b}}$ & $4.70 \pm 0.72^{\mathrm{c}}$ & $6.80 \pm 0.23^{\mathrm{ab}}$ \\
$(50: 50)$ & $6.81 \pm 0.87^{\mathrm{ab}}$ & $6.73 \pm 0.66^{\mathrm{ab}}$ & $6.68 \pm 0.75^{\mathrm{ab}}$ & $5.90 \pm 0.53^{\mathrm{b}}$ & $7.06 \pm 0.38^{\mathrm{a}}$ \\
$(0: 100)$ & $7.26 \pm 0.43^{\mathrm{a}}$ & $7.00 \pm 0.23^{\mathrm{a}}$ & $7.03 \pm 0.40^{\mathrm{a}}$ & $6.96 \pm 0.62^{\mathrm{a}}$ & $7.18 \pm 0.30^{\mathrm{a}}$ \\
\hline
\end{tabular}

This is due to CPC having high protein content as indicated in Table 1. Fat content of cookie obtained from different ratios of wheat flour and CPC varied from 18.25 to $23.75 \%$. The highest fat content was found in wheat flour cookies. Cookies from CPC: WF (90:10) contained the highest amount of ash $(2.98 \%)$ whereas the lowest was observed in the control cookies (100\% wheat flour). Results for carbohydrate content and calorie revealed significantly highest in wheat flour cookie $(61.56 \%$ and $539.43 \mathrm{Kcal} / 100 \mathrm{~g}$, respectively). The carbohydrate content and calorie of cookies decreased with the degree of substitution of CPC for wheat flour increases.

\subsection{Sensory Evaluation}

The means sensory liking scores for appearance, color, flavor, texture, adhesiveness and overall liking of noodles are shown in Table 4. Most panelists scored the cookies substituted with $50 \%$ CPC-pI to be similarly acceptable as the control cookies ( $0 \%$ CPC) for color, odor, flavor and overall liking. It was observed that the sensory liking scores of the texture attributes of cookies were significantly different when the CPC was replaced from $50 \%$ to $90 \%$; the texture of cookies was harder than that of the control. The panelists scored all attributes of the cookies substituted with more than 50\% CPC-pI less than those of the control and 50\% substitution cookies. These results may be due to the CPC-pI itself having high protein content, strong odor and darker color, as a result, the cookies had dark color, hard texture and affect the overall liking. However, the study suggested that even though the overall liking of cookies was less than that of the control cookies, the low carbohydrate and low calorie cookies were valued. It is promising for producing other functional food products.

\section{DISCUSSION}

It was found that the protein content of CPC obtained from all methods had high enough protein to be the protein concentration. This is defined as the protein content in protein concentration products that ranges between 65 and 90\% (CODEX standard 175-1989), whereas protein isolate products must be greater than or equal to $90 \%$ of protein content. The protein concentration, prepared using pI precipitation, had higher protein. This may be due to alkaline conditions by adjusting $\mathrm{pH}$ to 8 before adding hydro chloric acid to $\mathrm{pH}$ 4.5. This can increase the solubility of proteins because an alkali condition can break the disulfide bonds in the protein molecule and cause protein to dissolve more and extracted effectively prior to precipitation.

The amount of total amino acids in protein concentrate from cowpea was different significantly $(p \leq 0.05)$. The values are directly proportional to the amount of protein content in the CPC. The more the protein is the more amount of amino acids in the CPC-pI. This may be due to the fact that amino acid is the composition of the protein.

A similar isoelectric point was observed in some plant protein isolate such as walnut (Mao and Hua, 
2012). A protein in an aqueous system has a zero net charge at its isoelectric point and no migration arises. At $\mathrm{pH}$ values above and below the isoelectric point, the protein solubility gradually increased. Protein molecule has a positive or negative charge at $\mathrm{pH}$ values above and below the isoelectric point, where more water increases with protein charges (Mao and Hua, 2012).

The reduction or increase in the ability to hold water varies according to the type of salt used and may be associated with the positive and negative charge on the protein molecule and electrostatic interactions between the water molecules. Moreover, the low WHC of CPC$\mathrm{AM}$ may be due to the CPC-AM contained non-polar amino acids which are low in water binding capacity. The CPC-pI was able to bind more oil than the CPCAM-pI and CPC-AM. This may be because the alkaline condition of $\mathrm{NaOH}$ enhanced the extraction of protein and the salt unfolded the protein molecule causing it to display more hydrophobic (Ragab et al., 2004) and therefore the protein molecule was able to bind more oil.

Factors affecting the foaming protein depend on several factors such as solubility, concentration of protein, pH, shape and size of the protein (Zayas, 1997). The CPC-pI had the highest foaming ability. This may due to the extraction of protein by $\mathrm{pH}$ adjustment having high solubility and high concentration. As a result, it was capable of high foaming activity. The stability of the foam decreased when standing for a long time. This may be because of the protein denature and protein molecule unfolding causing hydrophobic regions to open more, consequently, making it impossible to maintain the foaming stability and then causing the collapse of the foam bubble (Phillips and Beuchat, 1981). In addition, the stability of the bubble is the result of the rheology property of the protein film and the charge density on the protein molecule (Damodaran, 1996).

The emulsifying capacity depends upon the hydrophiliclipophilic balance of soluble protein (Wu et al., 2009). At the oil-water interface, the protein oriented lipophilic residues to the oil phase and hydrophilic residues to the aqueous phase, thus reducing surface tension at the interface. The increase in protein solubility assisted interaction between the oil phase and the liquid phase. The emulsifying stability of CPC was similar to that of protein solubility. The CPC-pI showed the greatest emulsifying stability. This was in agreement with the correlation found between emulsifying stability and nitrogen solubility in the study of (Ragab et al., 2004).

The stability of the emulsion declined indicating that the salt may result in the separation of oil and water. This mechanism may be due to the reduction of the surface tension, the strength of the surface of the protein film and a change of the charge. The salt also may reduce the charge repulsion between proteins and an increase in aggregation of hydrophobic molecules on the surface may also lead to an increase in the coalescence of emulsion. As a result, the stability of the emulsion decreased. This could be the reason for the stability of the CPC-AM being low (Mao and Hua, 2012).

The gelation results from the ability of protein to absorb water. The gelation was affected by the concentration of the protein and the expression of hydrophobic amino acid in the protein.

From the solubility results, it helped to make clear that the solubility decreases as the $\mathrm{pH}$ increases until it reaches the isoelectric point and then increases. The loss of electrostatic repulsive forces presents beneficial conditions for the formation of protein to aggregate give rise to precipitation of protein and then the protein solubility increases with further increase of $\mathrm{pH}$ (Singh et al., 2005).

\section{CONCLUSION}

The results suggested that cowpea protein concentrate had desirable functional properties. The cowpea protein concentrate prepared by isoelecpoint precipitation indicated better water holding capacity, oil binding capacity, foam stability and emulsifying properties. Moreover, when the CPC-pI was applied to replace wheat flourin cookie, the results revealed that protein concentrate could be used to replace wheat flour as high as $60 \%$. This suggested that cowpea protein concentrate is likely to be used in food systems.

\section{ACKNOWLEDGMENT}

The study was financially supported by Mahasarakham University, Thailand, grant number 2556A10902065

\section{ADDITIONAL INFORMATION}

\subsection{Funding Information}

Mahasarakham University (Fiscal year 2013)

\subsection{Author's Contributions}

All authors of this research article have directly participated in the planning, execution and analysis of this study.

\subsection{Ethics}

The contents of this manuscript will not be copyrighted, submitted, or published elsewhere. There are no directly 
related manuscripts, published or unpublished, by any authors of this study. My Institute's, Mahasarakham University, representative, is fully aware of this submission.

\section{REFERENCES}

AOAC, 2000. Official Methods of Analysis. Association of Official Analytical Chemist International. 17th Edn., AOAC International, Gaithersburg, MD, USA.

AACC, 2011. Annual Meeting Abstracts. Am. Associat. Clin. Chem., Washington.

Coffman and Garcia, 1977. Proceedings of the ... annual conference. Federal University of Technology, Akure (Nigeria). School of Agriculture and Agricultural Technology. Annual Conference, Indiana University.

Damodaran, S., 1996. Amino Acids, Peptides and Proteins. In: Fennema, O.R. (Ed.,), Food Chemistry Marcel Dekker, Inc., New York, ISBN-10: 9780824793463, pp: 321-430.

Fernandez-Quintela, A., M.T. Macarulla, A.S. Del Barrio and J.A. Martínez. 1997. Composition and functional properties of protein isolates obtained from commercial legumes grown in Northern Spain. Plant Foods Hum. Nut., 51: 331-342. DOI: 10.1023/A:1007936930354

Lampart-Szczapa, E., 1996. Preparation of protein from lupin seeds. Food/Nahrung, 40: 71-74. DOI: 10.1002/food.19960400205

Lawal, O.S., K.O. Adebowale, B.M. Ogunsanwo, O.A. Sosanwo and S.A. Bankole, 2004. On the functional properties of globulin and albumin protein fractions and flour of African locust bean (Parkia biglobossa). Food Chem., 92: 681-691. DOI: 10.1016/j.foodchem.2004.08.043

Liceaga-Gesualdo, A.M. and E.C.Y. Li-Chan, 1999. Functional Properties of fish protein hydrolysate from herring (clupea harengus). J. Food Sci., 64: 1000-1004. DOI: 10.1111/j.13652621.1999.tb12268.x

Mao, X. and Y. Hua, 2012. Composition, structure and functional properties of protein concentrates and isolates produced from walnut (Juglans regia L.). Int. J. Molecular Sci., 13: 1561-1581. DOI: 10.3390/ijms13021561

Mutilangi, W.A.M.D. and A. Panyam 1996. Kilara functional properties of hydrolysates from proteolysis of heat-denatured whey protein isolate. J. Food Sci., 61: 270-275. DOI: 10.1111/j.13652621.1996.tb14174.x
Ogunwolu, S.O., F.O. Henshaw, H.P. Mock, A. Santros and S.O. Awonorin, 2009. Functional properties of protein concentrates and isolates produced from cashew (Anacardium occidentale L.) nut. Food Chem., 115: 852-858. DOI: 10.1016/j.foodchem.2009.01.011

Phillips, R.D. and L.R. Beuchat, 1981. Enzyme modification of proteins. Protein Functionality Foods.

Quinn, J.R. and D. Paton, 1979. A practical measurement of water hydration capacity of protein materials. Am. Associat. Cereal Chem., 56: 38-40.

Ragab, D.D.M., E.E. Babiker and A.H. Eltinay, 2004. Fractionation, solubility and functional properties of cowpea (Vigna unguiculata) proteins as affected by $\mathrm{pH}$ and/or salt concentration. Food Chem., 84: 207212. DOI: $10.1016 / \mathrm{S} 0308-8146(03) 00203-6$

Rodriguez-Ambriz, S.L., J.J. Islas-Hernández, E. Agama-Acevedo, J. Tovar and L.A. Bello-Pérez, 2008. Characterization of a fibre-rich powder prepared by liquefaction of unripe banana flour. Food Chem.,. 107: 1515-1521.

Sasanam, S., Paseephol, T. and Moongngarm, A. 2011. Comparison of proximate compositions, resistant starch content and pasting properties of different colored cowpeas (Vigna unguiculata) and red kigney bean (Phaseolus vulgaris). World Acad. Sci. Eng. Technol., 81: 525-529.

Sathe, S.K., S.S. Deshpande and D.K. Salunkhe, 1982. Functional properties of lupin seed (Lupinus mutabilis) proteins and protein concentrates. J. Food Sci., 47: 491-497. DOI: $10.1111 /$ j.13652621.1982.tb10110.x

Singh, N., M. Kaur and S.S. Kawaljit, 2005. Physicochemical and functional properties of freezedried and oven dried corn gluten meals. Drying Technol., 23: 975-988. DOI: 10.1081/DRT200054253

Wu, H., Q. Wang, T. Ma and J. Ren, 2009. Comparative studies on the functional properties of various protein concentrate preparations of peanut protein. Food Res. Int., 42: 343-348. DOI: 10.1016/j.foodres.2008.12.006

Yu, J., M. Ahmedna and I. Goktepe, 2007. Peanut protein concentrate: Production and functional properties as affected by processing. Food Chem., 103: 121-129. DOI: 10.1016/j.foodchem.2006.08.012

Zayas, J.F., 1997. Functionality of Proteins in Food. Springer-Verlag, Berlin, Germany, ISBN: 978-3642-63856-5 